SCIREA Journal of Agriculture

http://www.scirea.org/journal/Agriculture

March 7, 2021

SCIREA

Volume 6, Issue 1, February 2021

\title{
Colorado River: Solutions for better use and Environmental Protection.
}

\author{
María I. Escobosa, Fidel Núñez, Víctor A. Cárdenas, Roberto Soto Ortiz, S. Mónica \\ Avilés, Aurelia Mendoza \\ Institute of Agricultural Sciences, Autonomous University of Baja California, Mexico \\ Email: iescobosa@uabc.edu.mx (María I. Escobosa)
}

\begin{abstract}
The Colorado River, with a distance of over 2,300 kilometers, is one of rivers that present greater conflict between its states users, who have had to live around water resources in order to achieve mutual benefits. It is observable all the Mexican side is frequently suffer the negative impacts in terms of allocations in terms of quantity and quality of water. Before the construction of large dams along its course; Colorado River fed one of the largest desert estuaries in the world. Located on the northern edge of the Gulf of California, vast freshwater wetlands, once covered 780,000 ha (1 930,000 acres) and hosted a legendary wealth of plants, birds and human life.

After nearly five decades of inactivity, the currents flow again on the Colorado River, On March 23, 2014, thanks to the treaty "Pulse flow" in "minute 319", 105,000-acre-foot , (130 million cubic meters) a very positive event, the result of long negotiations between Mexico and the United States. The pulse flow experiment is expected to flood low terraces and backwaters, move sediment, elevate the water table, and promote the germination of cottonwood and willow tree.
\end{abstract}


In another case, the administration of the Irrigation District Mexicali Valley.

Planning is required in the distribution of water to farmers in the Mexicali Valley; working together in the case of a single river between the two districts of Imperial Valley and Mexicali Valley.

Work should be done together while the Colorado River is our only source of water for human consumption and agricultural production, which requires the use and knowledge management, through good management practices of irrigation water and fertilizer. Use surface water drainage that meets the classification according to the classification of irrigation water can recycled for use of irrigation water.

The increased values of environmental quality and habitat throughout the basin, so that the river bed to recover, and prevent the loss of endemic species. Change some habits they have and thus reduce the consumption of the liquid.

Keywords: Irrigation District, Drought, minute 319, pulse flow.

\section{INTRODUCTION}

The International Water Treaty of 1944 states that Mexico has a guaranteed volume of 1850.23 million cubic meters a year (Mm3 / a) in normal, same flow received by two control points: Jose Maria Morelos Dam and SIB North and Sanchez Mejorada Canal Sur -Treaty International on the Utilization of Waters of the Colorado, Tijuana and Bravo signed by the presidents of Mexico and the United States on February 3, 1944.

Currently, Delta conditions have changed. The Colorado River Delta has been greatly altered by human activity. for decades they have been dammed and diverted water in Mexico and the United States, and this has reduced the Delta to a system of small wetlands. While dams captured water, fresh water left to get to Delta, and indeed during the decade of the 70 'and 80 ' both the mainstream press and scientific, referred to Delta as a dead and dry system. From 1980 to 1998 , releases water to the Delta has reached $20 \%$ of total flows from the Colorado River. 
The Colorado River is the source of life for the southwestern United States and northwestern Mexico. Colorado trans boundary basin covers an area of over 630,000 km2 in which live more than 30 million people in both countries.[9]

The impacts of management of the Colorado River have affected more drastically in the delta at the mouth of the river in the Upper Gulf of California. Located in the states of Sonora and Baja California, the delta has all the impacts that have accumulated along the basin.

At the entrance of Colorado to Mexico, Morelos Dam, Baja California, the river flow is reduced to the amount of water that the US must deliver to Mexico according to the International Treaty of 1944. At this point, Mexico derives volumes remaining to be allocated to different human uses. The river, its wetlands and Upper Gulf usually run out of fresh water.

The State of Baja California, according to the National Institute of Statistics, Geography and Informatics (INEGI), the General Census of Population and Housing 2010 for the State of Baja California, notes that a population of 3.155 million people registered. However, for 2014, based on projections of the population, 3.5 million people are estimated, not counting the population is known as "floating", so in practical terms, the population of the Bank is located in more than four million inhabitants. Of According to the same INEGI, the population of Baja California is distributed in five municipalities: Tijuana, Tecate, Ensenada, Rosarito and Mexicali. Being the city of Tijuana, the most densely populated, with around two million inhabitants, followed Mexicali with just over one million people. The city and port of Ensenada, recorded around half a million inhabitants; 165000 Tecate and Rosarito, recently (in 1995), it has a population of 110 thousand inhabitants.

\section{Water in the cities of Baja California.}

According to its climatic characteristics, the five municipalities are classified as arid and semi-arid. The municipalities of the Costa del Pacific, present conditions of Mediterranean climate and absence of water bodies that will provide the supply of water they consume. The municipality of Mexicali, which is the only one of five that is located on desert area, and is also the only water available permanently, so paradoxically, is that currently supplies water to the Most of the state's population, and could be the future supply of water for the rest of the entity. 
The municipality of Mexicali has two sources of water permanently: water from the Colorado River and water drawn from the underground aquifer of the region. The availability of the two sources of water in the municipality of Mexicali, are due to the presence of the runoff, surface and subsurface of the Rio Colorado, whose birth is established in the Rocky Mountains of the States of Wyoming, Colorado and Utah, Union Americana. The long and winding career of more than 2500 kilometers, reached Mexican territory in the states of Baja California and Sonora, where the delta area of this important river is located.

In terms of availability of water resources, only the municipality of Mexicali has sufficient volume to provide water, permanently, the entire population using this valuable resource. The rest of the municipalities do not have sufficient resources to meet water demand, this constitutes a very serious problem that affects most of the population, for many years now.

Thanks to the negotiations of Mexican diplomats, it was possible the signing in 1944 of the Water Treaty, in which the US government is committed to deliver to Mexico, an annual turnover of Colorado River water for 1,850 million m3 ( MMCA), which has been possible to develop economic and social activities, raised by the authorities. The other source of water available in the city of Mexicali, comes from the underground aquifer, which means the operation of approximately 1,000 deep wells pumping a volume is drawn to 1.2 billion cubic meters of water, so in Overall, the municipality of Mexicali has a volume of 3000 million m3 per year (MMCA).

Irrigation District 014, Río Colorado, is the third largest in Mexico, with a total of 86 districts. It is located northwest of the Mexican Republic. It comprising the municipalities of Mexicali, Baja California and San Luis Rio Colorado, Sonora. Its altitude above sea level (m) varies from 43 meters, 5 meters. Created in December 1939 (Presidential Decree of August 23, 1938, and November 16, 1955). It comprising a total area of 328,000 hectares, of which 250,000 are compacted irrigation district. The surface irrigation rights of 207.965 hectares, with 16,500 users. The purchase of 27000 hectares of land for real estate, does not include irrigation rights. For the administration, operation and maintenance of the works, the National Water Commission operates Works Head in Main Canal $27 \mathrm{~km}$ Reform; $7.5 \mathrm{~km}$. Main Canal Revolution, and wells and gutters Sandy Mesa de San Luis Rio Colorado. Mayor Channel Network is concessioned to a Limited Liability Company, IP user (SRL), which is responsible for operating and maintaining the works. The SRL on the control points (16), CNA receives water volumes authorized, then deliver them to Gravity irrigation modules. Well users operate differently. Minor Channels Network operates and maintains over 22 
irrigation modules. Each module is in charge of a Civil Association of Users, which provides irrigation services to farmers under the Concession Agreement of the Federal Government, through the National Water Commission. [1].

\section{The Earthquake April 4 in Mexicali, Baja California, México \& Caléxico}

\section{CA. USA.}

On April 4, 2010, it is recorded in Valle de Mexicali \& Imperial Valley Earthquake 7.2 degrees Richter scale damaged water infrastructure in irrigation modules 11, 12 and part of 10. June 17, 2010, minute no. 317 was signed Commissioner IBWC, Roberto Salmon asks the US government to allow water storage of 23 hectares. The December 17, 2010, minute 318 [6]. IBWC signed accepts Mexican farmers to store water for the period 2010 until 31 December 2013. It accepts the provisions of minute 318.[7]

The November 20, 2012, is signed minute 319 [7]. It is established that Mexico accepts that the United States will retain water equivalent to irrigate 18000 hectares, and these are stored in Hoover Dam, until December 31, 2017, with the possibility of it until December 31, 2025; minute no. 319 allows further cooperation on river management. That new criteria for drought, water conservation projects and the implementation of an environmental component that allows the allocation of 195 million cubic meters of water for nature are established through equal contributions from Mexico, USA and civil society organizations. These environmental flows were called "Flow Pulse" and "Base Flow". Pronatura Noroeste with partners Raise The River Coalition has been instrumental in the negotiation and implementation of minute no.319 [7] and the restoration of the Colorado River delta.

\section{Environmental conservation is the main objective of the agreement "Pulse flow" on the Colorado River}

The "Pulse flow" is the first international agreement to release volumes of water with the sole purpose of environmental conservation, and forms part of the measures Mexico-US joint cooperation established in the minute no.319 - signed at the end of 2012- which provides providing water to restore life to the Colorado River Delta and rescue the ambient environment. 
Besides the protection of about 380 species of endemic birds, the water flow will allow the recharge of aquifers favoring farmers and generating significant environmental benefits.

The actions of this bilateral agreement are based on technical studies and do not imply damages to water for human, agricultural or industrial use, since scientific experts from both nations determined that this is the best time of year to implement the pulse flow

\section{Drought in California (USA).}

On April 1 the state governor, Jerry Brown issued an executive order to implement the cuts and approved "reduction plan that could be put into effect before the summer, when water consumption increases."

The plan includes more than 400 water suppliers to reduce supply between eight and 36 percent, depending on the level of consumption of the residents.

According to figures provided by the board, the savings in water consumption last summer totaled 8.6 percent through March.

Traditionally the authorities estimate that between eight and 50 percent of residential water use occurs during the summer outdoors and represents the best opportunity to save.

Unprecedented restrictions set how people, governments and companies should use water and start to be implemented from June. [5] LOS ANGELES, May 7 2015.- For the first time in the history of California, the State Board of Control of Water Resources (AWRCB, for its acronym in English) approved an emergency plan which sets a cut of 25 percent the supply of the vital liquid.

The plan approved unanimously at the meeting that establishes cut urban water supply by 25 percent as a measure to reduce consumption and thus face the worst drought in the history of California.

We are in a massive drought and facing something that had never before, "said Felicia Marcus, secretary AWRCB. 


\section{What is drought?}

The World Meteorological Organization [11], in its International Meteorological Vocabulary defines drought as "a period with abnormally dry weather, long enough for the lack of precipitation to cause a serious hydrological imbalance."

The United Nations, in its document of the Convention to Combat Desertification (UN, 1994) defines drought as "naturally occurring phenomenon that exists when precipitation has been significantly below normal recorded levels, causing serious hydrological imbalances that adversely production systems of land resources "

[10] In his paper "Understanding and Defining Drought" define four types of drought, according to their origin and their effects are:

Weather: It refers to the degree of deviation of rainfall compared to a "normal" behavior, a number of preset time. However the magnitude of the deviation and time are not fixed, but rather depend on the way regionally evaluate the phenomenon, for example, for the United States in 1942 it was considered drought if rainfall is less than 2.5 millimeters in 48 hours; for Britain in 1936 criteria 15 days consecutive drought was proposed with a total accumulated rainfall less than $0.25 \mathrm{~mm}$.; Libya in 1964, when annual rainfall is less than 180 $\mathrm{mm}$; and India when seasonal precipitation is less than twice the average deviation.

However, there is agreement to draw the meteorological drought as the first indicator of the phenomenon of drought.

Agriculture: it is closely related to meteorological drought and its impact on crops, consider the process in terms of moisture balance, is it evaluates the actual evapotranspiration, potential water deficit in the soil which in turn depends on physical characteristics thereof, the water reserve levels and considers crop specificity in their moisture requirements, depending on the growth stage and plant biology, and states that this type of drying may occur after the presence of a drought weather type.

Hydrology: It is referred to the effects of relatively short periods of rainfall, it is the runoff at surface level and underground, its impact is reflected in groundwater recharge, lakes, dams and their impact is long term, is, while agricultural drought has an immediate effect on crops, hydrological drought can affect agricultural production in several years, hydroelectric production or extraction of groundwater. 
Socioeconomic: It rises in terms of water supply and demand by humans, so it is closely related to the effects of short and long term other types of drought. The drought occurs when water demand of a social group, in a particular place exceeds supply, is a combination of reduced rainfall and the growing needs of the population or production activities efficiency in water use and available technology.

[10] They say: The drought is a natural process erratic, arising as a result of a deficiency of precipitation over an extended period of time, usually a season or more, thus causing a water imbalance, thus affecting human and environmental activities; it is a poor state of precipitation in relation to an average considered normal behavior.

Drought in Irrigation District.

Returning types of drought, in Mexicali, as mentioned receives 1,850 million cubic meters, so we do not require rain to define what a drought. In the Valley of Mexicali and Imperial Valley rains an average of $76 \mathrm{~mm}$ and have a evaporation of $2000 \mathrm{~mm}$. [8], we are blessed by the Colorado River; Drought in Irrigation District, concerned about the excessive use of water, misuse or misallocation (could be mentioned as deficient management Irrigation District).

\section{CONCLUSION}

The work must be done jointly whereas the Colorado River is our only source of water for human consumption and agricultural production, which require the use and management awareness, through good management practices of irrigation water and fertilizer. In accordance with [4]; [2); [3], recommending that the surface drainage water that complies with the classification according to the classification of irrigation water.

To avoid drought should be done jointly whereas the Colorado River is our only source of water for human consumption and agricultural production, which require the use and management awareness, through good management practices and irrigation water fertilizers, agriculture include conservation.-Plan and execute the writing.

Increasing environmental and habitat quality values throughout the basin, so that the riverbed recovers, and prevent the loss of endemic species. 
Change some habits they have and thus reduce the consumption of the liquid.

Drought definition is the anthropogenic effect by failing to respect the planet and thus cause climate change.

\section{REFERENCES}

[1] Calleros, Jesus Adolfo. 2014. EL ACTA 319 de CILA: Estrategia Binacional ante la Sequía. Congress in Tempe, Arizona.

[2] Bali, K.M., M.E. Grismer y I.C. Tod. 2001. Reduced Runoff Irrigation of Alfalfain Imperial Valley, California Journal of Irrigation and Drainage Engineerin/May/June $2001 /$ pp 123-130

[3] Escobosa, M.I., Bali, K.M., Guerrero, Juan., Soto O. R., Escoboza, L.F., Pérez M. A. Cárdenas S. V.2009. Efecto de la Calidad del Agua de Drenaje Superficial y su re-uso Mediante Practicas de Aplicacián de Fosforo en Alfalfa (Medicago sativa), en el Valle Imperial. Agrofaz, Marzo. ISSN: 1665-8892. Pp 49-56

[4] Grismer M.E. and Bali, K. M. 2001. Reduced Run-Runnof Irrigation of Sudan Grass Hay, Imperial Valley, California, American Society of Civil Enginneers, Journal of Irrig. \& Drain. Engr. Vol 127. No. 5, pp. 319-323.

[5] http://www.excelsior.com.mx/global/2015/04/02/1016685\#imagen-2

[6] http://www.ibwc.gov/Files/Minutes/Minute_319.pdf

[7] http://www.ibwc.gov/Files/Minutes/Min_318.pdf

[8] Meybery, K.S., and Meister H. 2003. University of California Coorporative Extension. Cost of production, Field Crops.

[9] Osvel Hinojosa y Yamilett Carrillo.2013. Atals, Las Cuencas Hidrogáficas de México. Cuenca binacional del Rio Colorado.pp. 180-185.

[10] Wilhite, D.A. y Glantz, M.H. (1985). "Understanding the drougth phenomenon: the role of definitions", Water international, vol 10: 111-120.

[11] World Metereological Organization. 1992. Manual on the global data processing and forecasting system. 